\title{
Anti-nutritional Composition, Heavy Metal Content and Mineral Bioavailability of Red Tree Vine (Leea guineensis G. Don) Fruits
}

\author{
M. B. Olaniyi*, S. O. Rufai \\ Biomedicinal Research Centre, Forestry Research Institute of Nigeria, PMB 5054, Jericho Hills, Ibadan, Nigeria \\ * Corresponding author email: musbay2012@gmail.com
}

Received: 03 October 2019 / Revised: 04 December 2019 / Accepted: 07 December 2019 / Published: 08 December 2019

\begin{abstract}
Leea guineensis G. Don is an evergreen shrub that has been reported to be important in Nigeria due to its medicinal and nutritional uses. However, there is paucity of documented information on the antinutritional composition, heavy metal content and mineral bioavailability of L. guineensis whole fruits. Hence, this study investigated the essential minerals, heavy metals and anti-nutritional compositions of L. guineensis whole fruits with a view to assess the quantity, bioavailability of the mineral elements and ultimately the safety of the fruits using standard analytical procedures. The results of phytochemical screening confirmed presence of secondary metabolites in varying quantities. The anti-nutrient contents (mg/100g) were phytates (29530); oxalates (510); saponins (10333); alkaloids (30533) and tannins (53.3). The results of mineral analysis revealed that L. guineensis fruits were rich in essential minerals (mg/100g) like, potassium (493); calcium (200); magnesium (103.3); phosphorus (9.9); zinc (8.5); manganese (5.5) and iron (5.0). The heavy metals concentrations were in the order lead $>$ chromium $>$ nickel $>$ cobalt $>$ cadmium. The values obtained were within the WHO permissible limits for heavy metals in medicinal plants. Meanwhile, the results of molar ratio phytates: Ca (8.97); oxalates: $\mathrm{Ca}(0.7978)$ and Ca.phytates: $\mathrm{Zn}(0.64)$ were below the suggested critical values indicating the bioavailability of calcium to be high. While phytates: Fe (501.06) and phytates: $\mathrm{Zn}$ (348.22) were higher than the critical values indicating poor bioavailability of $\mathrm{Fe}$ and $\mathrm{Zn}$. The study therefore suggests that L. guineensis fruits are a good source of phyto-minerals which can be harnessed for nutritional purpose. Also, the anti-nutrient contents in L. guineensis whole fruits should be reduced to a safe level through processing methods (soaking, de-pulping or fermentation) in order to achieve its optimum nutritional or medicinal use.
\end{abstract}

Keywords: Anti-nutrients, Bioavailability, Heavy metal, Mineral composition, Leea guineensis, wild fruits

\section{Introduction}

Fruits are the vital part of human diet owing to the enormous health benefits they render including disease prevention and improving overall wellbeing. They contain array of nutrients including vitamins, minerals, bioactive compounds and useful phytochemicals especially antioxidants which help in lowering risk of chronic diseases like coronary heart diseases, hypertension. Fruits are naturally rich in dietary fibre, ascorbic acid, potassium, iron and low in sodium, calories and fat [1]. Wild fruits are potential source of antioxidants, vitamins and minerals which also act as an important source of nutrient to the rural dwellers [2]. In most developing nations, several types of edible wild plants are utilised as sources of food to provide alternative nourishment to the local inhabitants. In recent years, there has been a growing interest to evaluate various wild edible plants for their nutritional characteristics in order to promote their utilization and acceptability as an alternative source of essential nutrients (minerals) and means of enhancing livelihood [3]. 
Meanwhile, the main functions of minerals which can be derived from wild fruits are confirmed by Anita et al. [4] who reported that minerals are necessary for normal cellular functions as they provide additional protection to the human body and act as secondary players in some biochemical cascade mechanisms. Also, Sanchez-castillo and James [5] inferred that optimal intake of minerals such as sodium, potassium, magnesium, calcium, manganese, copper and zinc could potentially reduce risk factors associated with cardiovascular and other degenerative diseases. Though, it has been reported that some fruits especially the wild edible fruits contain some levels of anti-nutrients (phytates, oxalates, tannins, alkaloids, saponins and many more) which diminish useful nutrient bioavailability specifically when they are found in high levels [6]. As a result, the anti-nutrient factors must be determined to ensure human and animal nutritional security. The nutritional value and antinutrient content of wild edible fruits have not been given much attention they deserved such that massive volume of these wild fruits are often wasted or eaten by wild animals. However, a possible way of achieving nutrition security is through careful exploitation and utilization of available, cheap nourishing wild edible fruits like Leea guineensis [7]. Anti-nutrients have been described as substances that impair or inhibit important metabolic pathways especially digestion of some essential nutrients. For instance, phytates possess a high density of negative charges due to the presence of phosphate groups which make phytates form stable complexes with calcium, manganese, iron, copper and zinc resulting in precipitation and subsequent unavailability for intestinal uptake [8]. According to Hallberg and Rossander [9], the ascorbic acid helps iron absorption by making iron less vulnerable to phytate complexation thereby increasing its bioavailability. Park [10] submitted that the free oxalates released from food after digestion result insoluble calcium oxalates formation which then reduces the amount of calcium available for absorption in the intestinal lumen. It was also confirmed that oxalates remove calcium from the blood in the form of $\mathrm{Ca}$-oxalates which may cause gallstone leading to kidney damage [11].
Leea guineensis Linn commonly called red tree vine is an evergreen shrub or small tree belonging to the family Leeaceae with single, trifoliate or feathered leaves. It is locally called Alugbokita in Yoruba and Okatakyi in Twi Language [12]. L. guineensis is native to tropical Africa countries which include Cote d'Ivoire, Liberia, Sierra Leone, Ghana, Cameroon and Nigeria. The fruits of $L$. guineensis are usually rounded, yellow when immature and pink or brown when matured [12]. L. guineensis has been reported to be important in Nigeria due to its medicinal and nutritional uses. Neji et al. [13] reported that L. guineensis is commonly used in the treatment of several ailments such as toothache, gonorrhoea, general weakness, skin lesions, rashes, ulcer, diarrhoea, dysentery, boils, herpes, paralysis, epilepsy and spasm, convulsions as a diuretic, pain-killer and purgative. L. guineensis fruits contain appreciable amounts of vitamin A, C, D and E [12]. They also possess bioactive constituents and exhibit antibacterial and antifungal properties.

In the developing countries like Nigeria where mineral deficiencies are common among rural dwellers, increasing the bioavailability of mineral in the food is of utmost concern. L. guineensis fruits could provide a cheap source of nutrients which can improve the nutritional status, reduce the prevalence of malnutrition especially among resource-constrained households and also serve as a means of dietary diversification. The presence of anti-nutrients is one of the major setbacks limiting the nutritional qualities of the food [14]. Wider utilization and acceptability of wild fruits is limited, due to the presence of anti-nutritional compositions which are associated with irritation, inflammation and gastrointestinal disturbances and may have negative effects on bioavailability of useful minerals [15]. Many reports on some underutilized wild seeds and fruits indicate that they could be good sources of nutrient for both man and animals [16]. However, L. guineensis has been considered as a wild fruit and there is limited information on its anti-nutritional composition and mineral bioavailability. This study therefore evaluated the essential minerals and heavy metal concentrations of L. guineensis whole fruits in order to know their quality and safety as well as their 
Olaniyi et al., Int. Ann. Sci.; Vol. 9, Issue 1, pp: 70-79, 2020

anti-nutrients to determine bioavailability of minerals.

\section{Materials and Methods}

\subsection{Sample collection and preparation}

Fresh, mature fruits of $L$. guineensis were collected from the Forestry Research Institute of Nigeria Herbal garden, Ibadan, Oyo state, Nigeria. The specimens were identified at the Forestry Herbarium Ibadan, Nigeria where a voucher specimen (FHI002019) was deposited. The whole fruits were cleaned, sorted and oven-dried at $55^{\circ} \mathrm{C}$ for 3 days in an electric oven at the Biomedicinal Research Centre, Forestry Research Institute of Nigeria, Ibadan to reduce the moisture content of the fresh fruits. The dried fruits were cooled to ambient temperature and subsequently ground to powder using household blender and the powdered samples were stored in air-tight containers. The samples were coded for chemical analysis and all the laboratory determinations were carried out in triplicates.

\subsection{Qualitative screening of phytochemical constituents of Leea guineensis fruits}

Leea guineensis plant is shown in Figure 1. Phytochemical screenings were carried out on the powdered sample using standard analytical procedures to confirm the presence of constituents (alkaloids, anthraquinones, flavonoids, saponins, tannins, steroids, cardiac glycosides and total phenolic compounds) as described by [17], [18] and [19].

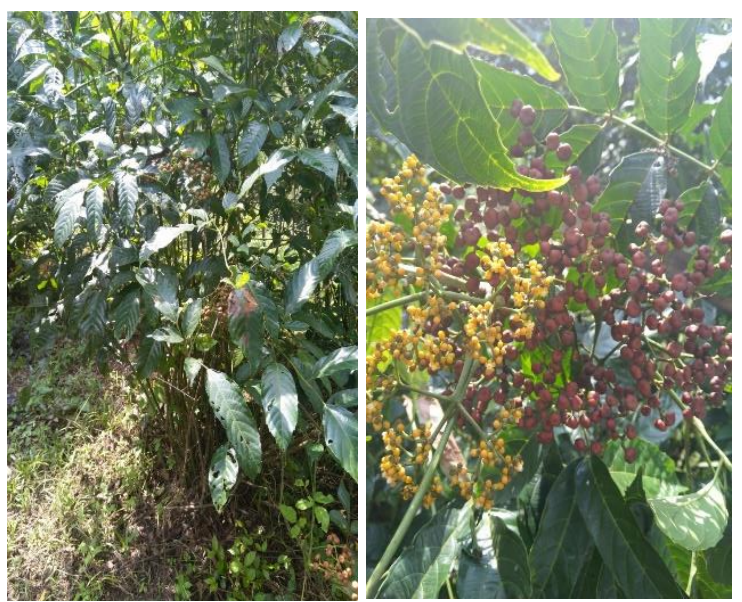

Figure 1: Leea guineensis plant (Source: FRIN Herbal Garden)
Test for saponins was done where $1 \mathrm{~g}$ of powdered sample was boiled with $10 \mathrm{~mL}$ of distilled water in a bottle bath for $10 \mathrm{~min}$. The mixture was filtered while hot and allowed to cool. Frothing test was done where $2.5 \mathrm{~mL}$ of filtrate was diluted to $10 \mathrm{~mL}$ with distilled water and shaken vigorously for 2 minutes. Appearance of frothing indicated the presence of saponins in the filtrate. Also, emulsifying properties was tested on the sample where 2 drops of olive oil were added to the solution obtained from diluting $2.5 \mathrm{~mL}$ of filtrate to $10 \mathrm{~mL}$ with distilled water (as above), then shaken vigorously for a few minutes. The formation of persistent foam was evidence of the presence of saponins. Test for alkaloids was carried out by stirring $1 \mathrm{~g}$ of sample in $10 \mathrm{~mL}$ of concentrated $\mathrm{HCl}$ on a steam bath followed by filtration. Filtrate $(1 \mathrm{~mL})$ was mixed with two drops of Wagner's reagent, then two drops of Dragendorff's reagent were added to another 1 $\mathrm{mL}$ of the filtrate in a different test tube, and the two mixtures were then observed for turbidity. Presence of tannins was done where powdered sample (1 g) was boiled with $20 \mathrm{~mL}$ of distilled water in a water bath and was filtered while hot. Then, cooled filtrate $(1 \mathrm{~mL})$ was made up to $5 \mathrm{~mL}$ with distilled water and 3 drops of $10 \%$ ferric chloride were added and observed for any formation of precipitates and any colour change. A bluish-black or brownish-green precipitate indicated the presence of tannins. Flavonoids were tested for by boiling $1 \mathrm{~g}$ of sample with 10 $\mathrm{mL}$ of ethanol and 2 drops of ferric chloride were added to $5 \mathrm{~mL}$ of the extract. The mixture was observed for a dusty green colouration as positive result. Test for free anthraquinones was carried out where sample $(0.5 \mathrm{~g})$ was shaken with $5 \mathrm{~mL}$ of chloroform for $10 \mathrm{~min}$, filtered and $5 \mathrm{~mL}$ of $10 \%$ ammonium solution was added to the filtrate. The mixture was then shaken and the presence of a pink, red or violent colour in the ammonia phase confirmed the presence of free anthraquinones. Test for cardiac glycosides was done where $1 \mathrm{~g}$ of sample was extracted with $10 \mathrm{~mL}$ of $80 \%$ ethanol for $5 \mathrm{~min}$ on a water bath. The extract was filtered, diluted with equal volume of distilled water and two drops of lead acetate solution were added, then shaken and filtered after standing for 10 minutes. The filtrate was then extracted with 
aliquots of chloroform and the extract was dissolved in $2 \mathrm{~mL}$ of glacial acetic acid containing one drop of $\mathrm{FeCl}_{3}$ solution in a clean test tube. Concentrated $\mathrm{H}_{2} \mathrm{SO}_{4}$ acid $(2 \mathrm{~mL})$ was then poured down the side of the tube so as to form a layer below the acetic acid. The formation of a reddish brown or brown ring at the interface and a green colour in the acetic layer was taken for a positive result. Test for phenolic compounds was done by soaking sample $(1 \mathrm{~g})$ in $25 \mathrm{~mL}$ of $2 \%$ of $\mathrm{HCl}$ for 1 hour then, filtered through a $10 \mathrm{~cm}$ Whatman No. 1 filter paper. The extract $(5 \mathrm{~mL})$ was mixed with $1 \mathrm{~mL}$ of $0.30 \%$ ammonium thiocyanate solution with 3 drops of ferric chloride solution. A brownish-yellow colour indicated the presence of phenols.

\subsection{Determination of anti-nutrients}

The anti-nutrient contents of $L$. guineensis whole fruits were determined using various standard analytical procedures. Aluminium chloride method was adopted for the determination of total flavonoids content of the sample according to Quettier-deleu et al. [20] while, alkaloids determination was done according to the quantification method as described by Harborne [21]. Total saponins were determined according to the method of Obadoni and Ochuko [22] with slight modifications. Estimation of tannins was carried out using the modified vanillin- $\mathrm{HCl}$ method [23]. Total phenolic content of the sample was estimated according to the method described by Lister and Wilson [24] with slight modification. Oxalates content was determined according to the method described by [25]. Phytates content was carried by an indirect colorimetric method of Wheeler and Ferrel [26]. Glycosides were determined according to the method described by Sofowora [27].

\subsection{Determination of mineral contents}

Minerals and heavy metal content of $L$. guineensis whole fruits were determined according to standard analytical procedures of [25]. The mineral sodium and potassium were determined by flame photometry, while other trace elements such as iron and zinc and the heavy metals such as nickel, cobalt, chromium and lead were determined by acid digestion method with a mixture of nitric and perchloric acid (6:2) at 100 ${ }^{\circ} \mathrm{C}$. The digested sample was used for measurement of above minerals using an Atomic Absorption Spectrophotometer (AAS, SP9 model). Phosphorus was determined using potassium phosphate as the standard in a spectrophotometer (Spectronic 20 model, Gallenkamp UK).

\subsection{Determination of Mineral bioavailability}

In this study, the bioavailability of minerals (calcium, magnesium, iron and zinc) was calculated as reported by Woldegiorgis et al. [28]. The molar ratio between anti-nutrients (phytates and oxalates) and minerals ( $\mathrm{Ca}$ or $\mathrm{Fe}$ or $\mathrm{Zn}$ ) was obtained after dividing the mole of anti-nutrient with the mole of mineral. The mole of phytates (phytic acid) was calculated as the measured value of phytic acid divided by the molecular weight of phytic acid while the mole of various minerals $(\mathrm{Ca}$ or Fe or $\mathrm{Zn}$ ) was calculated as the measured value of the mineral divided by the individual mineral molecular weight.

\subsection{Statistical analysis}

Data were analysed using the descriptive statistical analyses where means and standard deviation (SD) were obtained using Microsoft Excel 2013 version. Results were expressed as mean \pm SD

\section{Results}

The result of phytochemical screening of $L$. guineensis whole fruits confirmed the presence of various phyto-constituents including antinutrients in the sample in varying degrees from slightly present to abundant (Table 1).

Table 1: Qualitative phytochemical screening of $L$. guineensis fruits (dry basis)

\begin{tabular}{|c|c|}
\hline Parameters & Result \\
\hline Alkaloids & + \\
\hline Anthraquinones & + \\
\hline Cardiac glycosides & + \\
\hline Flavonoids & + \\
\hline Phenols & + \\
\hline Saponins & + \\
\hline Steroids & + \\
\hline Tannins & + \\
\hline Terpenoids & + \\
\hline \multicolumn{2}{|c|}{+ means present } \\
\hline
\end{tabular}


Olaniyi et al., Int. Ann. Sci.; Vol. 9, Issue 1, pp: 70-79, 2020

Alkaloids, anthraquinones, cardiac glycosides, flavonoids, phenols, steroids tannins were found to be in abundance while saponins and terpenoids were slightly present. The result of anti-nutritional content of $L$. guineensis whole fruits revealed the presence of various anti-nutrients in varying concentrations (alkaloids $>$ phytates $>$ flavonoids $>$ saponins $>$ oxalates $>$ tannins) most especially the main anti-nutrients; phytates, oxalates and saponins were 29530, 10330 and 516.67 (mg/100g) respectively as presented (Table 2).

Table 2: Anti-nutritional content of L. guineensis fruits (dry basis)

\begin{tabular}{|c|c|}
\hline Parameters & $\begin{array}{c}\text { Composition } \\
\text { (mg/100g) }\end{array}$ \\
\hline Alkaloids & $30533 \pm 0.05$ \\
\hline Flavonoids & $10900 \pm 0.01$ \\
\hline Oxalates & $516.67 \pm 0.01$ \\
\hline Phytates & $29530 \pm 0.18$ \\
\hline Saponins & $10330 \pm 0.06$ \\
\hline Tannins & $53.30 \pm 0.01$ \\
\hline
\end{tabular}

Values are presented as mean $\pm \mathrm{SD}$ of triplicate measurements

Table 3: Mineral composition and Heavy metal content of L. guineensis fruits (dry basis)

\begin{tabular}{|c|c|}
\hline Parameters & $\begin{array}{c}\text { Composition } \\
\text { (mg/100g) }\end{array}$ \\
\hline \multicolumn{2}{|c|}{ Macro elements } \\
\hline Calcium & $200 \pm 0.000$ \\
\hline Magnesium & $1033 \pm 0.001$ \\
\hline Potassium & $492.66 \pm 0.001$ \\
\hline Phosphorus & $9.90 \pm 0.000$ \\
\hline Sodium & $218.33 \pm 0.001$ \\
\hline \multicolumn{2}{|c|}{ Trace elements } \\
\hline Iron & $5.00 \pm 0.00$ \\
\hline Manganese & $5.50 \pm 0.00$ \\
\hline Copper & $5.46 \pm 0.00$ \\
\hline Zinc & $8.43 \pm 0.00$ \\
\hline \multicolumn{2}{|c|}{ Heavy metals } \\
\hline Cadmium & $0.008 \pm 0.000$ \\
\hline Chromium & $0.927 \pm 0.000$ \\
\hline Cobalt & $0.050 \pm 0.000$ \\
\hline Nickel & $0.750 \pm 0.000$ \\
\hline Lead & $3.67 \pm 0.000$ \\
\hline
\end{tabular}

Results for the mineral composition and heavy metal content of L. guineensis whole fruits shown in Table 3 revealed that the fruits contain macro/micro minerals (magnesium, potassium, sodium, calcium, phosphorus, zinc, magnesium, copper, iron) in varying amounts while and heavy metals (lead, chromium, nickel, cobalt, cadmium) were in minute quantities as evidenced in the concentrations obtained. Results obtained from the calculated molar ratios of anti-nutrients (phytates and oxalates) to mineral elements (calcium, iron, zinc) were in the order phytates: $\mathrm{Fe}$ $>$ phytates: $\mathrm{Zn}>$ phytates: $\mathrm{Ca}>$ oxalates: $\mathrm{Ca}>$ phytates: $\mathrm{Ca} / \mathrm{Zn}$ as shown (Table 4 ).

Table 4: Calculated molar ratios of anti-nutrients to mineral elements of L. guineensis fruits

\begin{tabular}{|c|c|c|}
\hline Parameters & $\begin{array}{c}\text { Calculated } \\
\text { molar ratio }\end{array}$ & $\begin{array}{c}\text { Critical } \\
\text { molar } \\
\text { ratio }\end{array}$ \\
\hline Phytates:Ca & 8.97 & 0.24 \\
\hline Phytates:Fe & 501.06 & 1.0 \\
\hline Phytates:Zn & 348.22 & 15.0 \\
\hline Oxalates:Ca & 0.79 & 2.5 \\
\hline$[$ Phytates $(\mathrm{Ca})] /[\mathrm{Zn}]$ & 0.64 & 1.0 \\
\hline
\end{tabular}

\section{Discussion}

\subsection{Phytochemical composition}

The presence of various phytochemical constituents such as alkaloids, cardiac glycosides, flavonoids, phenolics, saponins, tannins in the $L$. guineensis fruits reported in this study confirms their therapeutic uses and in conformity with the medicinal properties of secondary plant metabolites [29]. The result obtained in this study was similar to the reports of Awotedu et al. [30]. Alkaloids have been reported as the most potent and therapeutically important of all substances isolated from plants which may explain its use against stomach ache, dysentery, diarrhoea, vomiting, constipation and intestinal worms [31]. The detection of flavonoids and saponins in this study is in line with the results obtained for $L$. guineensis stem bark and leaves respectively by Neji et al. [13] and Fagbohun et al. [32]. According to the report of Lewis and Elvis-Lewis [33], saponins have been reported to have anti-inflammatory and cardiac depressant properties and restrain growth of carcinogenic cells, without necessary destroying the normal cells in the process. Phenol possesses anti-bactericidal and antimicrobial properties which have shown to exert preventive activity 
against infectious and degenerative diseases, inflammation and allergies through antioxidant, antimicrobial and proteins [30]. Steroids are of great importance in the pharmaceutical industry due to its function as sex hormones [34]. Olaleye et al. [35] reported cardiac glycosides reported as a potent remedy against cardiac arrest or renal failure. Tannins are known to have antiviral, antifungal, antibacterial and anti-tumour properties [27]; hence, the presence of tannins in L. guineensis fruits strongly supports its use in wound treatments, tumours, malaria and virginal discharge [36].

\subsection{Anti-nutritional components of Leea guineensis fruits}

The main anti-nutrient contents (alkaloids, phytates, oxalates, tannin and saponins) found in in varying quantities in the L. guineensis whole fruits are presented (Table 2). Anti-nutrients reduce the maximum utilization of nutrients especially proteins, vitamins and minerals, thus preventing optimal exploitation of the nutrients present in a food and decreasing the nutritive value [37]. Phytate impedes the absorption of phosphorus, calcium, iron, zinc and magnesium by forming complexes with them and reduces amino acid digestibility. This makes these minerals readily unavailable to the body [38]. However, the amount of phytates $(29530 \mathrm{mg} / 100 \mathrm{~g})$ obtained in this study was far higher than the 0.0006; 0.0064; 0.0027 and $0.0182 \mathrm{mg} / 100 \mathrm{~g}$ for Gardenia erubescens, Sclerocarya birrea, Diospyros mespiliformis and Balanites aegyptiaca fruits respectively [39]. The value obtained in this study was also higher than 0.01, 1510,1280 and $1100 \mathrm{mg} / 100 \mathrm{~g}$ reported for Gynochthodes umbellata, Mochis sylvestris, Citrullus lanatus and Carica papaya fruits respectively [40, 41]. These are more than the $0.1-0.6 \mathrm{mg} / 100 \mathrm{~g}$ that has been reported to pose mineral bioavailability problems [42]. Despite causing mineral bioavailability problems, phytate is an antioxidant and an anticancer agent. However, the presence of high levels of phytates and oxalates in human diets are therefore undesirable. Hence, it is therefore recommended that $L$. guineensis fruits should be subjected to processing method such as de-pulping soaking and roasting before consumption which have been reported to drastically reduce the anti-nutrients to a safe level [7]. In contrast, there is evidence that dietary phytate at low level may have health promoting role as an antioxidant, anti-carcinogens and may play an important role in keeping hypercholesterolemia and atherosclerosis in check [43]. Tannins had been reported to alter protein digestibility, negatively affecting the bioavailability of non-haemoglobin iron resulting in poor iron and calcium absorption [44]. However, its toxicity effects depend upon their chemical structure and dosage [37]. Tannin content of L. guineensis fruits $53.30 \mathrm{mg} / 100 \mathrm{~g}$ was higher than 0.0029; 0.0059; 0.0046 and $0.004 \mathrm{mg} / 100 \mathrm{~g}$ obtained for Gardenia erubescens, Sclerocarya birrea, Diospyros mespiliformis and Balanites aegyptiaca fruits respectively [39]. In contrast, the value obtained in this study is lower than 1950, 1370, 490 and $880 \mathrm{mg} / 100 \mathrm{~g}$ reported for Mochis sylvestris, Citrullus lanatus, Carica papaya and Ananas cosmos fruits respectively [41]. The value $53.30 \mathrm{mg} / 100 \mathrm{~g}$ obtained is far below 560 $\mathrm{mg} / 100 \mathrm{~g}$ recommended daily limit of tannic acid for man. Therefore, the toxicity effects of the tannin may not be significant. Fekadu et al. [37] stated that oxalates can exert a harmful effect on human nutrition and health especially by reducing calcium absorption and aiding the formation of kidney stones. Gemede and Ratta [45] also reported that high- oxalate diets can increase the risk of renal calcium oxalate formation in certain groups of people. Oxalate value $516.67 \mathrm{mg} / 100 \mathrm{~g}$ was higher than $0.0025 ; 0.0011 ; 0.0014$ and 0.0038 $\mathrm{mg} / 100 \mathrm{~g}$ obtained for Gardenia erubescens, Sclerocarya birrea, Diospyros mespiliformis and Balanites aegyptiaca fruits respectively [37] and 0.09, 0.052 . 0.55 and $0.079 \mathrm{mg} / 100 \mathrm{~g}$ obtained for Mochis sylvestris, Citrullus lanatus, Carica papaya and Ananas cosmos fruits respectively [41]. Oxalate is known to inhibit renal calcium absorption, especially at concentrations of about $45000 \mathrm{mg} / 100 \mathrm{~g}$ [46] therefore, the value obtained in this study is far less than the value that is postulated to be harmful. This suggests that the fruits may not pose any mineral absorption problems if consumed.

\subsection{Mineral composition of Leea guineensis fruits}

Fruits are commonly regarded as good sources of minerals with the major minerals, calcium, 
Olaniyi et al., Int. Ann. Sci.; Vol. 9, Issue 1, pp: 70-79, 2020

magnesium and potassium in high abundance. The micro minerals such as zinc, manganese and copper were present in trace amounts. Minerals are good for maintaining proper body function and good health. Though, its deficiency leads to increased susceptibility to infectious diseases due to weakened immune systems. Micro elements are associated with decreased DNA damage, maintenance of immune functions, reduced lipid peroxidation and inhibition of malignant cell transformation but their absence leads to numerous metabolic disorders [47]. In general, the levels of minerals obtained in this study were higher than the values reported for closely related edible, medicinal plants like Chrysophyllum albidum, Spondias mombin and Cola millenii fruits [48]. On the other hand, the obtained values were lower than the values reported for Gynochthodes umbellata fruits except for $\mathrm{Mg}, \mathrm{Na}, \mathrm{Cu}, \mathrm{Fe}$, and $\mathrm{Zn}$ [41].

Kermanshah et al [49] and Mlitan [50] reported that iron is an essential trace element for haemoglobin formation, normal functioning of central nervous system and in the oxidation of carbohydrates protein and fats. It also plays an active role in oxygen transfer in the body and low iron content causes gastrointestinal infection, nose bleeding myocardial infection [51]. According to Longo and Camaschella [52], iron deficiency results in anaemic condition when there is decreased level of red blood cells as a result of significant reduction of iron content in the human body. This condition can present a severe complication with adverse consequences for expectant mothers [53]. The concentration of iron $(5.0 \mathrm{mg} / 100 \mathrm{~g}$ ) obtained in this present study is higher than $0.85 ; 1.92$ and $2.17 \mathrm{mg} / 100 \mathrm{~g}$ obtained for Cola millenii, Irvingia gabonensis and Chrysophyllum albidum respectively but lower than $14.59 \mathrm{mg} / 100 \mathrm{~g}$ obtained for Spondias mombin [45]. Calcium is the major component of bone and assists in teeth developments, essential for blood coagulation and the integrity of intracellular cement substances [54]. From the report of Prasad [55], deficiency of calcium also known as hypocalcaemia leads to diseases such as osteoporosis and osteopenia. The quantity of calcium (200 mg/100g) obtained for L. guineensis fruits was higher than the values (6.48; $14.95 ; 8.81$ and $10.58 \mathrm{mg} / 100 \mathrm{~g}$ ) obtained for Gardenia erubescens, Sclerocarya birrea, Diospyros mespiliformis and Balanites aegyptiaca fruits [39]. This confirmed L. guineensis fruit as a good source of dietary calcium. Zinc is an essential trace element which plays an important role in various cell processes including normal growth, brain development, behavioural response, bone formation and wound healing [51]. A deficiency in zinc results in increased rate of diarrhoea, delayed wound healing process, impaired immune function and some psychological disorders [56]. In this study, quantity of zinc obtained (8.43 $\mathrm{mg} / 100 \mathrm{~g}$ ) was higher than $2.71 ; 1.52 ; 2.60 ; 1.73$ and $1.25 \mathrm{mg} / 100 \mathrm{~g}$ obtained for related edible fruits of Strychnos spinosa, Detarium microcarpum, Diospyros mespiliformis, Dialium guineensis and Gardenia tenifolia respectively. The heavy metals concentrations obtained in this study were 3.67, $0.75,0.927,0.05$ and $0.008 \mathrm{mg} / 100 \mathrm{~g}$ for lead, nickel, chromium, cobalt and cadmium respectively. These values obtained are harmless due to the fact they were within the WHO permissible or safe limits for heavy metals in medicinal plants.

\subsection{Molar ratios and bioavailability of minerals of Leea guineensis fruits}

The molar ratios for calcium, zinc, iron and phytate, oxalate were calculated to evaluate the effects of high levels of phytate and oxalate in the bioavailability of dietary minerals. Mineral bioavailability can be defined as the ability of the body to digest and absorb the mineral in the food consumed [37]. The calculated Phy:Ca, Phy: Zn, Phy: Fe, Ox: Ca and $\mathrm{Ca} P h y / Z n$ molar ratios of $L$. guineensis fruits in comparison with critical values are shown in Table 4. Woldergiorgis et al [28] reported that the phy: $\mathrm{Ca}$ molar ratio has been proposed as an indicator of $\mathrm{Ca}$ bioavailability and critical molar ratio of less than 0.24 indicating good calcium bioavailability. The value of phy:Ca 8.97 obtained in this study was higher than the reported critical molar ratio 0.24 indicating that absorption of calcium may be slightly affected by phytate content in the samples. Meanwhile, Hurrell et al. [57] confirmed that phytate starts to lose its inhibitory effect on iron absorption when phytate:iron molar ratios are less than 1.0 although even ratios as low as 0.2 exert some negative effect. The result 501.16 obtained for L. guineensis 
fruits indicates that the phytate:iron molar ratios of the sample is far higher than the critical value 1.0 which implies poor absorption of iron in the sample. In addition, zinc is another important dietary mineral of foodstuffs which depends on both the total zinc content and the level of other constituents in the diet that affect zinc bioavailability. Bhandari and Kawabata [58] stated that phytate may reduce the bioavailability of dietary zinc by forming insoluble mineral chelates at a physiological $\mathrm{pH}$ level which depends on relative amounts of both zinc and phytates. Hence, the phytate: $\mathrm{Zn}$ molar ratio is considered a better indicator of zinc bioavailability than total dietary phytate levels alone [28]. The values (348.22) obtained in this study was far higher than the critical molar ratios of Phy: $\mathrm{Zn}, 15.0$. This therefore indicates poor zinc availability in the sample according to the submissions of Morris and Ellis [59]. Furthermore, oxalic acid can pose harmful effects on human diet and health particularly by decreasing calcium absorption and helping the formation of kidney stones [58]. The function of oxalate contents in plant product in limiting total dietary $\mathrm{Ca}$ availability is of significance only when the ratio of $\mathrm{Ox}: \mathrm{Ca}$ is greater than one [60]. In this study, the value of Ox:Ca was 0.79 which is lower than the reported critical value (1.0). This implies that a low level of oxalate could have no adverse effects on bioavailability of dietary calcium in this sample. However, the potential effect of calcium on zinc absorption in the presence of high phytate intakes has led to the suggestion that the $[\mathrm{Ca}][\mathrm{Phy} /[\mathrm{Zn}]$ molar ratio may be a better index of zinc bioavailability than the [Phy]/ [Zn] molar ratio alone [61] therefore, high calcium levels in foods can promote the phytate-induced decrease in zinc bioavailability when the $[\mathrm{Ca}][$ phytate $] /[\mathrm{Zn}]$ value exceeds1.0 [62]. The value of $[\mathrm{Ca}][\mathrm{Phy}] /[\mathrm{Zn}]$ ratio in this study was 0.64 which is less than the critical level which then implies good zinc bioavailability in the sample studied. The bioavailability of $\mathrm{Fe}, \mathrm{Ca}$ and $\mathrm{Zn}$ may be affected by the phytate content which can be overcome by mild processing of fruit prior to consumption.

\section{Conclusion}

The study revealed that L. guineensis whole fruits were found to be a good source of dietary macro/micro elements with traces of heavy metal that is less than the quantity that can be harmful to health therefore these fruits can be recommended as a remedy to alleviate mineral deficiency in the country. The fruits of L. guineensis is edible and can therefore be integrated into human food and animal feed. In order to maximally tap the mineral content of L. guineensis fruits for better mineral bioavailability, the antinutrient contents need to be drastically reduced to safe level through processing methods such as soaking in water, depulping, seed removal, prior to consumption.

\section{Declarations}

\subsection{Acknowledgement}

Authors appreciate Dr. (Mrs) E.C. Odozie, the Head of Central Laboratory, Forestry Institute of Nigeria Jericho Hills, Ibadan, for her immense contribution during mineral analysis.

\subsection{Competing Interests}

Authors declare no conflict of interest on this publication.

\section{How to Cite this Article:}

M. Olaniyii and S. Rufai, "Anti-nutritional Composition, Heavy Metal Content and Mineral Bioavailability of Red Tree Vine (Leea guineensis G. Don) Fruits", Int. Ann. Sci., vol. 9, no. 1, pp. 70-79, Dec. 2019. doi:10.21467/ias.9.1.70-79

\section{References}

[1] H.N. Ene-obong, H.O. Okadu and U.V. Asumugba. "Nutrient and phytochemical composition of two varieties of monkey kola (Cola parchycarpa and Cola lepidota): an underutilised fruits". Journal Food Chemistry, 193, 154 - 159, 2016.

[2] S. Yashaswini, R.V. Hedge and C.K. Venugopal. 'Health and Nutrition from ornamentals'. International Research Journal of Pharmacy, 2(2), 375 - 382, 2011.

[3] K. Asha, K.P. Asish, J.R. Kumar and P. Ashok. 'Antioxidant activities, metabolic profiling, proximate analysis, mineral nutrient composition of Salvadora persia fruit: Unravel potential functional food and a natural source of pharmaceuticals'. Frontier Pharmacology, 8 (61), 1 - 14, 2017.

[4] S.S. Anita, E.J. Akpan, P.A. Okon and I.U. Umoren. Proximate composition and phytochemical constituents of leaves of some Acalypha species. Pakistan Journal of Nutrition. Vol. 5, 166 - 168, 2006. 
Olaniyi et al., Int. Ann. Sci.; Vol. 9, Issue 1, pp: 70-79, 2020

[5] C.P. Sanchez-castillo and W.P. James. The mineral content of Mexican fruits and vegetables. Journal of Food Composition and Analysis, Vol. 11(4), 340 - 356, 1998.

[6] C.U. Ogunka-Nnoka and H.D. Mepba, 'Proximate composition and anti-nutrient contents of some common spices in Nigeria", The Open Food Science Journal, vol. 2, pp. $62-67,2008$.

[7] M.B. Olaniyi, I.O. Lawal and A.A. Olaniyi, 'Proximate, phytochemical screening and mineral analysis of Crescentia cujete L. leaves"' Journal of Medicinal Plants for Economics Development, vol. 2, no. 1, pp. a28, 2018.

[8] H.W. Lopez, F. Leenhardt, C. Coudray and C. Remesy, "Minerals and phytic acid interactions - Is it a real problem for human nutrition"' Int. Journal of Food Sci. and Technol. vol. 37, pp. 727 - 739. 2002.

[9] L. Hallberg, M. Brune and L. Rossander, 'Iron absorption in man: Ascorbic acid and dose-dependent inhibition by phytate'. The American Journal of Clinical Nutrition, vol. 49, pp. 140 - 144. 1989.

[10] S.W. Park, 'Bioavailability analysis of oxalate and mineral content in selected edible mushrooms" Journal of Nutritional Disorders and Therapy, vol. 4, pp. $1-6$, 2013.

[11] S. Muhammad, L.G. Hassan, S.M. Dangoggo, S.W. Hassan, K.J. Umar and R.U. Aliyu, ' Nutritional and Antinutritional Composition of Sclerocarya birrea Seedkernel" Studia Universitatis "Vasile Goldiş", Life Sciences Series, vol. 21, no. 4, pp. 693-699, 2011

[12] B.O. Ajiboye, A.O. Oso and O.S. Kobomoje, 'Chemical composition and nutritional evaluation of Leea guineensis seed', Int. J. food Sci. Nutr. and Diet, vol. 3 no. 2, pp. 24 - 32, 2014.

[13] P.A. Neji, O.A Ushie, H.A. Neji, I.J. Opara and O.O. Ojong, 'Screening and Antimicrobial Activity of Extracts of Leea guineensis Stem Bark' International Journal of Modern Chemistry, vol. 9, no. 1, pp. 1-9, 2017.

[14] P. Kathirvel and P. Kumudha, 'Chemical composition of Prosopis juliflora (SW.) D.C (mosquito bean)' Int. J. Applied Biology Pharmaceutical Technology, vol. 2, pp. 5 - 14, 2011.

[15] H.F. Gemede, N. Ratta, G.D. Haki, A.Z. Woldegiorgis and F. Beyene, 'Nutritional quality and health benefits of okra (Abelmoschus esculentus L.): a review' Journal of Food Process Technology, vol. 6, pp. 485, 2015.

[16] V.A. Adekunle, O.V. Ogerinde, 'Food potentials of some indigenous wild fruit in lowland rainforests ecosystem of south west Nigeria"' Journal of Food Technology, vol. 2, pp. 12 - 130, 2004.

[17] J.B. Harborne, Introduction to ecological biochemistry, 4th edition, Academic Press, London, United Kingdom, 1993.

[18] G.E. Trease, and W.C. Evans, A textbook of Pharmacognosy, 13th edn., Bacilluere Tinal Limited, London, 1989.

[19] A. Sofowora, Medicinal Plants and Traditional Medicine in Africa Spectrum Books Limited, Ibadan Nigeria, pp. $191-289,1993$.

[20] C. Quettier-Deleu, B. Gressier, J. Vasseur, T. Dine, C. Brunet and M. Luyckx, 'Phenolic compounds and antioxidant activities of buckwheat (Fagopyrum esculentum Moench) hulls and flour' Journal of Ethnopharmacology, vol. 72 , pp. $35-42.2000$.

[21] J.B. Harborne, Phytochemical methods - A guide to modern techniques of plant analysis, 3rd editon, Springer Pvt. Limited, New Delhi, 2005.
[22] B.O. Obadoni and P.O. Ochuko, 'Phytochemical studies and comparative efficacy of the crude extract of some homeostatic plants in Edo and Delta states of Nigeria", Global Journal of Pure Applied science, vol. 86 pp. 203 208, 2001.

[23] M.L. Price, S.W. Van Scoyoc and L.G. Butler, ' A critical evaluation of the vanillin reactions as an assay for tannins in sorghum grain', Journal of Agric. Food Chemistry, vol. 26, pp. $1214-1218,1978$.

[24] E. Lister and P. Wilson, Measurement of total phenolics and ABTS Assay for Antioxidant Activity, Crop Research Institute Lincoln, New Zealand, 2001.

[25] Association of Official Analytical Chemists international (AOAC), Determination of Lead, Cadmium, and Minerals in Foods by Atomic Absorption Spectrophotometry Method (999.11/985.35), Association of Official Analytical Chemists, Gaithersburg, MD, USA, 2005.

[26] E.L Wheeler and R.E. Ferrel, ' A method for phytic acid determination in wheat and wheat fractions" Cereal Chemistry, vol. 48(3), pp. 312 - 320, 1971.

[27] A. Sofowora, Medicinal Plants and Traditional Medicine in Africa. 2nd editiond, Spectrum Books Limited., Ibadan, Nigeria, vol. 151153, pp. 209 - 214, 2006.

[28] A.Z. Woldegiorgis, D. Abate, G.D. Haki and G.R. Ziegler (2015). 'Major, minor and toxic minerals and antinutrient composition in edible mushrooms collected from Ethiopia', Food process Technology, vol. 6, pp.134 - 142, 2015.

[29] S.D. Oyeyemi, S. Arowosegbe and A.O. Adebiyi, 'Phytochemical and Proximate Evaluation of Myrianthus arboreus (P. Beau) and Spargono sporgonophora (L.) Leaves 10SR"' Journal of Agric. and Vet. Sci. vol. 7, no.9, pp. 125, 2014.

[30] O.L. Awotedu, P.O. Ogunbamowo, I.B. Emmanuel and I.O. Lawal (2019). 'Phytominerals and phytochemical studies of Azadirachta indica, Leea guineensis and Parkia biglobosa". International Annals Science, vol. 6, no.1, 28 $-34,2018$.

[31] D.E. Okwu, 'Phytochemicals, Vitamins and Minerals contents of two Nigeria Medicinal Plants" International Journal of Molecular Medicinal Advanced Science, vol. 1, no. 4, pp. 140 - 147, 2005.

[32] E.D. Fagbohun, O.U. Lawal and M.E. Ore, 'The Proximate, Mineral and Phytochemical Analysis of the leaves of Ocimum gratissimum L., Melanthera scandens A. and Leea guineensis L. and their Medicinal value", International Journal of Applied Biology and Pharmaceutical Technology, pp. 15 - 20, 2012.

[33] W.H. Lewis and M.P. Elvis-Lewis, 'Medicinal Plants as sources of new therapeutics"' Ann. M. Bot. Gard. vol. 82, pp. $16-24,1995$.

[34] D.E. Okwu, 'Phytochemicals, Vitamins and Minerals contents of two Nigeria Medicinal Plants', International Journal of Molecular Medicinal Advanced Science, vol. 1, no. 4 , pp. 140 - 147, 2001.

[35] M.T. Olaleye, "Cytotoxicity and Antibacterial Activity of Methanolic Extract of Hibiscus sabdariffa'" Journal of Medicinal. Plants Research, vol. 1, pp. 9-13. 2007.

[36] L. Taylor, Bitter melon, "Herbal properties and actions", in L. Taylor (ed.), The healing Power of rainforest herbs, Rain tree Nutrition Incorporation., New York, pp. 1 - 5, 2005.

[37] H. Fekadu, F. Beyene and G. Desse, ''Effect of traditional processing methods on nutritional composition and antinutritional factors of anchote (Coccinea abyssinica 
(Lam.) Cogn) tubers grown in western Ethiopia', Journal of Food Process Technology, vol. 4, pp. 249, 2013.

[38] M.O. Bello, O.S. Falade, S.R. Adewusi and N.O. Olawore, 'Studies on the chemical compositions and anti-nutrients of some lesser known Nigeria fruits" African Journal of Biotechnology, vol. 7, no. 21, pp. 3972 -3979, 2008.

[39] M.A. Achaglinkame, R.O. Aderibigbe, O. Hensel. B. Sturm and J.K. Korese, "Nutritional characteristics of four Underutilized edible wild fruits of dietary interest in Ghana', Foods vol. 8, no. 3, pp. 104, 2019.

[40] O. A. Matthew, I. Hashim, O.B. Titilayo, B.S. Rasaq, Z.M. Benjamin, J.F. Francis. 'Nutrient and Anti-Nutrient Composition of Shea (Vitellaria paradoxa C. F. Gaertn) Kernel and Pulp in the North East Nigeria'. International Journal of Sciences, vol 7 (9):56 - 66, 2018.

[41] E. Ekpa and D. Sani. Phytochemical and anti-nutritional studies on some commonly consumed fruits in Lokoja, Kogi state of Nigeria, General Medicine Open. Vol. 2(3): pp. $1-5,2018$.

[42] L.U. Thompson, 'Potential health benefits and problems associated with anti-nutrients in foods" Food Research International, vol. 26, pp. 131 - 149, 1993.

[43] B.Q. Phillippy, M. Lin and B. Rasco, 'Analysis of phytate in raw and cooked potatoes" Journal of Food Composition Analysis, vol. 17, pp. 217 - 226, 2004

[44] E.O. Adeparusi, 'Effect of processing on the nutrients and anti-nutrients of Lima bean (Phaseolus lunatus L.) flour' Nahrung, vol. 4, pp. 94 - 96, 2001.

[45] H.F. Gemede and N. Ratta, 'Anti-nutritional factors in plants foods: potential health benefits and adverse effects"' International Journal of Food Science, vol. 3, pp. $284-289,2014$.

[46] I. Muhammed, S. Muh, S. Olorunju, J. Bale, U. Abdullahi, R. Lawal, 'Response of nutrients and anti-nutritional constituents in the seeds of Cassia tora (Linn.) to treatments"' J. Agric. Environ., vol. 3, pp. 225-234, 2002.

[47] C.J. Rosen, "Sugar and Bone: A Not-So Sweet Story", Journal of Bone and Mineral Research, vol. 23, no. 12, pp. $1881-1883,2009$

[48] I.O. Olayiwola, V.O. Akinfenwa, C.O. Oguntona, S.A. Sanni, O.O. Onabanjo and W. A. Afolabi, 'PPytonutrient, antioxidant and mineral composition of some wild fruits in south West Nigeria", Nigerian Food Journal, www.nifst.org NIFOJ, vol. 31, no. 2, pp. 33 - 40, 2013.

[49] A. Kermanshah, P. Ziarati, J. Asgarpanah and M. Qomi, 'Food values of two endemic wild Almond species from Iran', Int. J. Plant Animal and Environmental Sciences, vol.4, pp. 380 - 388, 2003.

[50] A.M. Mlitan, M.S Sasi and A.M. Alkherraz, 'Proximate and minor mineral content in some selected basil leaves of Ocimum gratissimum L. in Libya" Int. J. Chem. Eng. Appl., vol. 5, 8-17, 2014.

[51] R. Ullah, J.A. Khader, I. Hussain, N.M. AbdElsalam, M. Talha and N. Khan, "Investigation of macro micronutrients in selected medicinal plants" African Journal of Pharmacy and Pharmacology, vol. 6, no. 25, pp. 1827 1832, 2012.

[52] D.L. Longo and C. Camaschella, 'Iron Deficiency Anaemia" New England Journal of Medicine, vol. 373, no. 5 , pp. $484-486,2015$.

[53] C. Breymann, ' 'Iron Deficiency Anaemia in Pregnancy a review', Semin Hematol, vol. 52, no. 4, pp. $339-347$, 2015 .
[54] J.C. Okaka and A.N. Okaka, Food Composition, Spoilage and Shelf life extension, ocjarc, Academic Publishers, Enugu, Nigeria, pp. 54 - 56, 2001.

[55] A. Prasad, (Ed.) Essential and toxic element: Trace elements in human health and disease. Amsterdam, Elsevier, 2013.

[56] B.O. Lonneral, 'Dietary factors influencing Zinc absorption" Journal of Nutrition, vol.130, no. 5, pp. $13785-13835,2000$.

[57] R.F. Hurrell, M.B. Reddy, M.A. Juillerat and J.D. Cook, 'Degradation of phytic acid in cereal porridges improves iron absorption by human subjects', American Journal Clinical Nutrition, vol. 77, pp. 1213 - 1219, 2003.

[58] M.R. Bhandari and J. Kawabata. 'Assessment of antinutritional factors and bioavailability of calcium and zinc in wild yam (Dioscorea spp.) tubers of Nepal', Food Chemistry, vol. 85 , pp. $281-287,2004$

[59] E. Morris and R. Ellis, 'Usefulness of the dietary phytic acid/zinc molar ratio as an index of zinc bioavailability to rats and humans" Biological Trace Element Research, vol. 19, pp. $107-117,1989$.

[60] C. Frontela, M.L. Scarino, S. Ferruzza, G. Ros and Martinez, 'Effect of dephytinization on bioavailability of iron, calcium and zinc from infant cereals assessed in the Caco-2 cell model" World Journal of Gastroenterology, vol. 28, pp. 1977 - 1984, 2009.

[61] G. Obah and T.V. Amusa, "Nutritive value and antioxidant properties of cereal gruels produced from fermented maize and sorghum" Food Biotechnology, vol. 23, pp. $17-31,2009$

[62] F.O. Adetuyi, A.U. Osagie and A.T. Adekunle, 'Nutrient, anti-nutrient, mineral and bioavailability of Okra (Abelmoschus esculentus (L.) Moench)", American Journal of Food Nutrition, vol. 1, pp. 49 - 54, 2011.

Publish your books with AIJR publisher-

$\checkmark \quad$ Publish with ISBN and DOI.

$\checkmark \quad$ Publish Thesis/Dissertation as Monograph.

$\checkmark \quad$ Publish Book Monograph.

$\checkmark \quad$ Publish Edited Volume/ Book.

$\checkmark \quad$ Publish Conference Proceedings

$\checkmark \quad$ Retain full copyright of your books.

Submit your manuscript at books.aijr.org

Publish your research article in AIJR journals-

$\checkmark \quad$ Online Submission and Tracking

$\checkmark \quad$ Peer-Reviewed

$\checkmark \quad$ Rapid decision

$\checkmark \quad$ Immediate Publication after acceptance

$\checkmark \quad$ Articles freely available online

$\checkmark \quad$ Retain full copyright of your article.

Submit your article at journals.aijr.in 